\title{
The Creation Science Movement in Korea: A Perspective from the History and Philosophy of Science
}

Sang-yong Song*

\section{The Crime of Galileo}

Religion and science, the two great man-made cultural legacies on earth, have maintained a complicated and delicate relationship. Late nineteenth-century books that addressed the relationship between the two reflect extreme rationalism of the time and are focused on the conflict between them. Some of the major literature was written by William Edward Hartpole Lecky (1865), John William Draper (1875), and Andrew Dickson White (1896). ${ }^{1}$ Bertrand Russell's Religion and Science (1935), published in the early twentieth century, also belongs to this category. ${ }^{2}$ However, the research conducted by historians and philosophers of science

* Professor Emeritus, Faculty of Humanities, Hallym University, Chuncheon, South Korea / Life Fellow, The Korean Academy of Science and Technology, Seongnam, South Korea.

1 William E. H. Lecky, A History of the Rise and Influence of Rationalism in Europe, 2 vols (New York: D. Appleton, 1865); John W. Draper, History of the Conflict between Religion and Science (New York: D. Appleton, 1874); Andrew D. White, History of the Warfare of Science with Theology in Christendom. 2 vols (New York: D. Appleton White, 1896).

2 Bertrand Russel, Religion and Science (London: Thornton Butterworth, 1935), Chapter 10. 
today shows a different trend-religion did not always clash with science and, in fact, even contributed to the development of science at times. ${ }^{3}$

Western science was born out of the Greek tradition, unrelated to Christianity. However, when Christianity became the official religion of the Roman Empire, science came in touch with religion. Although Christianity did not mix easily with science, at the time it was not at complete odds with science either. It was only during the Middle Ages when the Church began to rule the West with absolute authority that troubles began to occur. First, the general religious atmosphere of the Middle Ages did not provide an adequate environment for piquing intellectual curiosity, which was a prerequisite for science. Science was not particularly oppressed, but the environment was not conducive to scientific research in medieval Europe.

A new problem arose when universities were established in the late Middle Ages. As Western Europe began to awake from a long slumber of the Middle Ages, translations of Greek science texts flooded the continent. Aristotelian science began to take hold in universities in the thirteenth century, and it soon captivated scholars and became the absolute authority in universities. When Aristotelian science, or more specifically its interpretations, began to spread with negative consequences for Christianity, the Church felt threatened and responded with a severe measure, issuing a Condemnation to ban the works of Aristotle in 1210. Although Aristotelian science was eventually absorbed into the official philosophy of the Church through Christian interpretations, some claim that this temporary oppression fueled skepticism of authority among scholars and ultimately aided the ushering in of modern science. This is because scientists from

3 John H. Brooke, Science and Religion: Some Historical Perspectives (Cambridge: Cambridge University Press, 1991); David C. Lindberg and Ronald L. Numbers, eds., God and Nature. Historical Essays on the Encounter between Christianity and Science (Berkeley: University of California Press, 1986); Denis R. Alexander and Ronald L. Numbers, eds., Biology and Ideology from Descartes to Dawkins (Chicago: University of Chicago Press, 2010). 
the Middle Ages played a different role than theologians, but most of them also served as members of the clergy.

The conflict between science and religion intensified with the Scientific Revolution in the seventeenth century, particularly surrounding the issue of cosmology. In 1543, Nicolaus Copernicus proposed the theory of a heliocentric world system, which contained an innovative idea that would later overturn the medieval way of thinking. However, it did not create much trouble at the time, since Copernicus enjoyed full confidence of the Church, and his book On the Revolutions of the Heavenly Spheres (De revolutionibus orbium coelestium), which was published around the time of his death, was written in Latin and therefore had virtually no influence on the public. A major conflict surrounding cosmology occurred half a century later with Galileo Galilei, who was an avid supporter of Copernicus. Galileo's astronomical observations made with his telescope plainly illustrated the errors of Aristotle's cosmology, which had stood firm for two thousand years. The Catholic Church welcomed Galileo's discovery, and Jesuit astronomers praised Galileo for his research.

Unfortunately, the lay people and lower-ranking clergy raised objections to Galileo's findings, arguing that the earth's rotation conflicted with the Bible. Galileo asserted that the Bible should not be taken literally but figuratively. His argument sparked anger among the clergy, who accused him of attempting to reinterpret the Bible, and the Church issued the Decree of the Index in 1616, banning Copernicus' work on heliocentrism. Galileo's Dialogue Concerning the Two Chief World Systems (Dialogo sopra i due massimi sistemi del mondo), published in 1632, became a problem, and the Church summoned him before the Inquisition on suspicion of heresy. Under the threat of physical torture, Galileo abjured his scientific convictions, declaring his firm belief in the immovability of the earth. The Church did not want more than this submission.

This series of events, known as the Galileo affair, was not a simple conflict between enlightened reason and blind faith; there were a number of complicated factors involved. First, the Galileo affair was more of a strong conflict of personalities between Galileo and Pope Urban VIII. 
Second, punishing Galileo was the Church's indirect warning to the Protestants. The Council of Trent (Concilium Tridentinum) in the sixteenth century prohibited the interpretation of the scriptures that went against the consensus of the clergy and kept the arbitrary interpretations of the Lutherans in check.

Historians studying the Galileo Affair after the nineteenth century tended to highlight Galileo as a great scientist who was shackled by the authoritarian Church. On the other hand, Catholic scholars went to the other extreme and defended Galileo's punishment by overlooking or denying the facts of the affair. The heart of the problem is whether or not Galileo received an order from the Church in 1616 not to teach the Copernican system either through writing or speech. Those who believe that there was such an order issued by the Church claim that Galileo made a false testimony in his trial, while scholars who believe otherwise argue that the Church falsely incriminated Galileo.

Arthur Koestler sees the Galileo affair as a case of science intervening in society, and Giorgio de Santillana criticizes the intolerance policy of religion. On the other hand, Jerome K. Langford believes that the Church needs to admit their error although he also criticizes Galileo. Stillman Drake disagrees with these opinions and states that the Galileo Affair was a fundamental conflict between authority and freedom. According to Drake, Galileo did not attack the Church, yet the Church believed that its authority was threatened by Galileo's views, and Galileo only forewarned about what would happen by officially denouncing the theory that would later be recognized as true. ${ }^{4}$

It is true that some of the strongest opposition to the new cosmology came from Protestant leaders, including Martin Luther and Philip Melanchthon. However, the argument that the Catholic Church did not oppress science is unconvincing. Some people argue that Copernicus' works were only banned for a short period of time and that the Church allowed

4 Song Sang-yong, "Chonggyo-wa Kwahak (Religion and Science)," Chonggyomunhwahakbo (Journal of Religious Science \& Culture) 9 (May 2012): 9. 
lectures on Copernican theory. Yet the Church prohibited the discussion of theories on black spots and many other lectures on new science in universities. Moreover, the publication of Copernicus' books was not allowed for about 300 years in Catholic countries, which attests to the obvious influence the Church's condemnation of Galileo had on science. In 1965, Pope Paul VI visited Galileo's hometown of Pisa to praise Galileo's scientific achievement and admit the Church's errors. In 1992, Pope John Paul II pardoned Galileo officially and apologized for the mistakes made by the Catholic Church, including Galileo's trial. Yet the controversy on the Galileo affair continues even until today. ${ }^{5}$

Although the aftereffects of the Church's condemnation of Galileo lasted for a while, they did not lead to a catastrophe. It was because the leaders of modern science were all devout Christians, and among them, Isaac Newton, who concluded the Scientific Revolution, even attempted to prove the justification for the scriptures through mechanics. However, Newtonian science brought deism, which conflicted with Christianity. In the eighteenth century, a heated debate occurred between the proponents of natural religion (deism) and religion based on revelation. The idea that the Bible is a unique and unerring revelation of God faced strong opposition. The new science damaged the Church's faith in biblical inspiration because: first, mechanical philosophy did not blend in with the Hebrew view of nature; and second, reason came to occupy a more important position in society, indoctrinating people with the belief that society would forever make progress.

\section{The Death and Rebirth of Adam}

The scientific theory that clashed with religion after cosmology was the

5 Song Sang-yong, "Ch'ŏndongsŏl-gwa Chidongsŏl, Ch'angjoron-gwa Chinhwaron (Heliocentric Theory vs. Geocentric Theory, Creation vs. Evolution)," Samok 80 (March 1982): 22-5; Song, "Chonggyo-wa Kwahak," 7-9. 
theory of evolution. The idea of evolution can be traced back to Greece, but it only emerged in the world of science after the modern era. Evolution was prevalent in philosophy and science in eighteenth-century France. Georges-Louis Leclerc, Comte de Buffon argued that living organisms were made up of organic molecules, and further advocated the evolution of organisms from inorganic substances. ${ }^{6}$ However, he was condemned by the Faculty of Theology at Sorbonne, suffering the humiliation of having to retract his assertions, and he also had to tread lightly around the Church. Jean-Baptiste Lamarck, who was influenced by Buffon, presented a more comprehensive evolutionary theory but was unable to provide a scientific mechanism to support his theory.

It was the publication of Charles Darwin's Origin of Species in 1859 that rattled the world with the theory of evolution. Darwin's evolutionary theory was distinctly different from his predecessors in two aspects. First, he presented a credible evolutionary mechanism called "natural selection." Second, his concept of "species" was a bold renouncement of the 2000 years of the Platonic idea and was surprisingly modern. Unfortunately, the opposition from the scientific community was intense, and the strongest attacks came from the Church.

With these theories proliferating, it became necessary to examine the status of humans in the universe. While Copernicus' heliocentrism degraded earth to the status of one of many planets, Darwinism demeaned humans to the status of animals. The Church, which held creationism as an absolute truth, received the strongest blow. Theologians were dumbstruck by the two resulting ideas implied by Darwin's evolutionary theory. First, if humans and primates shared the same ancestors, it meant that humans were no longer privileged beings created in the likeness of God. Second, if Darwin's idea that plants and animals (including humans) were results of natural selection was true, the argument for the existence of God based on design would be destroyed.

Upon encountering Darwinism, Christian theologians divided into two

6 Song, "Chonggyo-wa Kwahak," 11. 
groups. The fundamentalists who outright refused to consider evolutionary theory insisted that there were no errors in the scriptures. On the other hand, the few minor liberal theologians sought a compromise, arguing that evolution was a scientific fact. They asserted that organisms were created by God and evolved by the will of God. This compromise was an opinion of the minority but received support from many scientists who were in a difficult position due to the bold claims of Darwinism.

Many Christians have long believed in the inspiration of the scriptures, and from their belief they drew the conclusion that there could be no errors in the Bible. The Catholic Church repeatedly confirmed this at every opportunity, starting with the Council of Trent. Protestants, who also relied only on the scriptures, obsessed over the infallibility of the Bible as well. The shock waves that Darwinism sent around the world did not stop at damaging the dignity of humans; the bigger problem was that it shook the roots of the doctrine of biblical inspiration.

Theologians and scientists reached a compromise during Darwin's time: they recognized evolution as a fact, but also explained that the mysterious structure and progress of nature was not accidental and therefore occurred according to God's design. This position is closely related to the tradition of natural theology. William Paley's Natural Theology gained extreme popularity, and Darwin himself was influenced by the book in his school years. However, since the eighteenth century, the belief in the eternity of the basic structure of nature and God's wise design had begun to decline, and Darwin proposed the theory of natural selection, thinking that there was no need to prove the idea of God's design. ${ }^{7}$

Scientists who came after Darwin tended to reject the idea of divine design, but theologians and philosophers emphasized compromise. In the early twentieth century, Henri Bergson advanced the idea of the vital force (élan vital), which is immanent in all organisms and responsible for their becoming more complex beings, similar to the concept of orthogene-

7 Song Sang-yong, "Inmunhakja Tawin (Darwin as a Humanist)," Special Lecture, Korea Research Foundation, November 7, 2009. 
sis. The successors of his idea included Pierre Teilhard de Chardin, a Jesuit paleontologist, who affirmed evolutionary theory and advanced a new Christian interpretation of the theory. The power of the Church had considerably weakened by the time evolutionary theory was proposed, and therefore it would have been impossible for the Church to inflict the kind of oppression on science when cosmology was first proposed. Nevertheless, the pressure from the Church continued in direct and indirect forms, although evolutionary theory did not face serious hindrances from the Church aside from a bit of trouble caused in conflict with teleology.

The Church maintained its uncompromising attitude toward evolutionary theory even after the turn of the century, but the steady stream of requests from theologians to revisit old doctrines began to take effect. In the Catholic Church, there was a conservative movement to condemn evolutionary theory in the 1920 s, which was quelled when evolutionists submitted a report to Pope Pius XI. In a 1943 papal encyclical, Pius XII explained that interpreting the Bible requires more than just the rules of grammar and philology and emphasized the need to incorporate history, archaeology, ethnology, and other sciences in the interpretation of the Bible.

The Protestant Church had various opinions about the Scriptures. The conflict between fundamentalism and modernism was intense, but eventually modernism, which saw the Scriptures as records of human efforts to pursue religious and ethical truths, gained traction, making the possibility of the compatibility of the scriptures and science more understandable. In the United States, an absolute majority of biologists accepted evolutionary theory after the $1880 \mathrm{~s}$. In an attempt to restore the damaged reputation of science, many biologists emphasized the importance of cooperation rather than conflict. ${ }^{8}$

In the twentieth century, however, evolutionary theory and creationism

8 Ronald Numbers, "Creationism, Intelligent Design, and Modern Biology," in Biology and Ideology from Descartes to Dawkins, ed. Denis R. Alexander and Ronald L. Numbers (Chicago: University of Chicago Press, 2010), 307. 
collided head-on in the United States. The conflict occurred in Tennessee, a stronghold of conservative Protestantism. The Tennessee State Senate passed the Butler Act, which made it unlawful to teach evolution, arguing that evolutionary theory denies God's creation of humans written in the Bible and advocates the evolution of humans from lower forms. John Thomas Scopes, a science teacher at a public school in Dayton, Rhea County, challenged this law by implying during his class that evolutionary theory was correct. Scopes was arrested, and thus began his trial, commonly known as the Monkey Trial, and Dayton became the center of worldwide attention.

At the Scopes trial, William Jennings Bryan, a typical religious fanatic and prosecutor, and defense lawyers such as Clarence Darrow, supported by the American Civil Liberties Union (ACLU), engaged in a fierce battle of words. Bryan predicated that Darwinism was nothing but conjecture, a hypothesis, and therefore not science. Scopes was found guilty and was fined 100 dollars but announced after his trial that he would continue to stand against the Butler Act. Scopes took the issue all the way to the state supreme court, and only in 1967 was the anti-evolution act repealed. Reinhold Niebuhr, a Protestant theologian, called the Scopes trial, the "last act in the drama of ignorant piety challenging the march of science." It also was not the last. Adam had died in 1859 with the publication of Darwin's Origin of Species, but was reborn in the United States after the 1960s.

The center of the creationist movement is California, home to the Creation Research Society whose members include scientists with Master's and Ph.D. degrees, as well as the Institute for Creation Research, an affiliate of the Christian Heritage College in San Diego. The members of the above-mentioned society and institute believe in the following: ${ }^{10}$ first, the

9 Reinhold Niebuhr, "Christianity and Darwin's Revolution," in A Book That Shook the World, ed. Julian Huxley et al. (Pittsburgh: University of Pittsburgh Press, 1958), 33.

10 Henry M. Morris, Scientific Creationism (San Diego: Creation-Life Publishers, 
Bible is the word of God, and therefore all of its assertions are historically and scientifically true; second, all basic types of living things, including humans, were created during the Creation Week described in Genesis; and third, the great flood described in Genesis was a historic event. The goal of the creationist movement in the 1920s was to drive out evolutionary theory from schools. After the 1960s, creationists made a strategic retreat and asserted instead that creationism should be given equal time as evolutionary theory in schools. Creationists, mostly consisting of physicists and engineers (and only a few biologists and geologists), point to problems in evolutionary theory and emphasize that creationism is science by using thermodynamics and the probability theory. However, their arguments tend to leave an impression that they are more religious than scientific.

\section{The Creation Science Movement in Korea}

The Korean Association for Creation Research (KACR) was founded in 1981, as a result of the "Creation or Evolution?" seminar, which had been held as part of the World Evangelical Crusade hosted by Minister Kim Chun'gon at the Campus Crusade for Christ auditorium from August 12 to $15,1980 .^{11}$ The lecturers for this seminar included Henry M. Morris, a founder and director of the Institute for Creation Research at the time, Duane Gish, Charles Thaxton, Walter Bradley, and Korea's Kim Yŏnggil (Kim Young-Gil). Then, on January 31, 1981, about four and a half months after the seminar, the KACR held its inaugural meeting at the

1972); Henry M. Morris, Introducing Creationism in the Public Schools (San Diego: Creation-Life Publishers, 1974); Duane T. Gish, Evolution: The Fossils Say No! (San Diego: Creation-Life Publishers, 1979).

11 Kim Young-Gil, "Ch'angjo Kwahak Sayŏk 20 nyŏn-ŭl Torabomyŏ” (Looking back to twenty years of the creation science mission)," in Han'gukch'angjogwahakhoe Isimnyŏnsa: 1981-2001 (Twenty-Year History of the Korean Association for Creation Research, 1981-2001) (Seoul: Han'gukch'angjogwahakhoe, 2001). 
Federation of Korean Industries Head Office Building. The founding president was Kim Yŏnggil and vice president was Ch'oe Yŏngsang. The association had 54 regular members and 40 associate members. The KACR actively hosted lectures, seminars, and published their research. According to Ronald Numbers' The Creationists, the KACR, which was imported from the United States, acquired over 1,000 members within a decade (of whom 300 hold doctorates) and also founded several branch offices in the United States. ${ }^{12}$ In its early days, the association received support from most press companies, with the exception of liberal newspapers, mainly Kyunghyang Shinmun and the Hankyoreh. Even Philosophical Quarterly published a special feature on "Religion and Fanaticism" and seemed hesitant to criticize creation science. Having gained broad support from the Korean Church, creation science succeeded in establishing a bridgehead in schools as well. Creation scientists stirred trouble by publishing the Introduction to Natural Science (Ch'angjogwahak Kaeron) as a textbook for college students and filed a lawsuit when their middle school and high school science textbooks (which contained ideas of creationism) failed to pass the verification process. However, creation science continued to receive a lot of support from the Korean Church, similar to the United States. There was even a liberal denomination that has contributed tens of millions of wons to the KACR.

In the year following the founding of the KACR, the Institute of Natural Sciences at Inha University held a symposium under the title "Evolution versus Creation," where many scientists (including evolutionist Yang Sŏyŏng (Yang Suh Yung)) explored the problems of creation science. The institute invited the KACR to the symposium to discuss the issue, but the KACR rejected the invitation. All of the presenters at the symposium were scientists. This author participated and was the only historian and philosopher of science. I submitted criticisms of creation science in this

12 Ronald Numbers, Ch'angjoronjadŭl (The Creationists: From Scientific Creationism to Intelligent Design), trans. Shin Chunho (Seoul: Holy Wave Plus, 2016), 418. 
symposium as well as in a number of media. ${ }^{13}$ My criticisms often encountered strong refutations from creation scientists, but I have not engaged in any debates.

Creation science thrived due to overflowing anti-science sentiments and the rise of conservatism. When people's optimistic expectations of science were shattered, strong waves of anti-science movements began in industrialized countries in the late 1960s. As part of such movements, mysticism and astrology flourished while signs of religious revival became more pronounced in the United States where science and technology are most advanced. According to Dorothy Nelkin, a sociologist of science, creation scientists blamed the collapse of families, moral corruption, and Communism on science, and evolutionary theory became a scapegoat. ${ }^{14}$ Perhaps similarities can be drawn between the wave of conservatism that swept the United States and the presidential election of Ronald Reagan, who advocated creation science since his days as the governor of California, and the coup d'état instigated by Chun Doo-hwan after the collapse of the Park Chung Hee administration.

There have been many questions concerning creation science and whether it qualifies as science. This brings us to examine the definition of science. The dictionary defines science as the "knowledge about or study of the natural world based on facts learned through experiments and ob-

13 Song Sang-yong, "Adam-ŭi Chugŭm-gwa Puhwal (The Death and Rebirth of Adam)," Kyobomun'go 1-2 (1982); “Ch'ŏndongsŏl-gwa Chidongsŏl, Ch'angjorongwa Chinhwaron)"; "Saeroun Tojŏn Pannŭn Chinhwaron (The New Challenge to Evolutionary Theory)," Chŏnggyŏngmunhwa 207 (1982); “Ch'angjokwahak-ŭn Kwahagin'ga? (Is Creation Science a Science?)," Kwahak-gwa Kisul (Science and Technology) 16, no. 9 (1983); “Ch'angjokwahak Undong (Creation Science Movement)," Hallym Hakpo 19 (1986); "Ch'angjokwahak-gwa Minjoksagwan (Creation Science and Nationalist View of History)," Saehan Shinmun, June 23, 1986; "Chinhwaron, Ch'angjosŏl and Ch'angjokwahak (Evolutionary Theory, Creationism and Creation Science)," Ŏlon-gwa Pip'yŏng 7 (1989).

14 Dorothy Nelkin, The Creation Controversy: Science or Scripture in the Schools (New York: Norton, 1982). 
servation." ${ }^{15}$ By this definition, Western science since the modern era is considered science. This narrow definition of science began to be challenged in the mid-twentieth century, and people began to accept that a coherent framework that does not necessarily rely on the scientific methods of the modern West is also science. This definition allowed "Chinese science" and "African science" to be classified as science as well. The ancient Ptolemaic astronomy, impetus mechanics of the Middle Ages, and the eighteenth-century Phlogiston chemistry were all science in themselves. Yet even with this broader definition of science, many scientists and philosophers criticized creation science, asserting that it cannot be considered science.

One who has studied logic might recall reductio ad absurdum (reduction to absurdity), which creation scientists use to point out the contradictions in denying creationism under the premise that God's creation as written in the Bible is an absolute truth. In the inaugural issue of science magazine Epi, which was published in the fall of last year, philosopher of science Jang Dayk (Chang Taeik) wrote an interesting article titled "Is Creation Science a Pseudo-Science?" Representative philosophers of science of the last century-Karl Popper, Thomas S. Kuhn, and Imre Lakatos-all argued that there is no doubt that creation science is pseudoscience, or faulty science at best because: ${ }^{16}$ science is something that can be disproven (Popper); there is no paradigm in creation science (Kuhn); and creation science is not a progressive research program (Lakatos).

However, there were many amateur scientists in the early days of the Scientific Revolution. Otto von Guericke, a seventeenth-century physicist known for the vacuum experiment, was the mayor of Magdeburg, while Joseph Priestley, who first discovered oxygen, was a Unitarian minister. But dilettantes are no longer the scholars of our society. Today, experts

15 "science," Merriam-Webster.com (2018), accessed August 6, 2018, https://ww w.merriam-webster.com.

16 Jang Dayk, “Ch'angjogwahak-ŭn Kacha Kwahak-in'ga? (Is Creation Science a Pseudoscience?)," Epi 1 (September 2017). 
who receive long and intense training are considered scientists. Scientists work in scientific communities that consist of experts in similar areas, and their achievements are evaluated by their peers in the said communities. If creation scientists truly wish to challenge evolutionists, they should change their fields of study to become biologists or geologists.

An interesting book on the subject matter has been written by Phillip Kitcher. Kitcher studied mathematics/history and philosophy of Science at Christ's College, University of Cambridge, which Darwin also attended. He then earned a doctorate in history and philosophy of science at Princeton University in the United States and settled down as a professor in the Department of Philosophy at Columbia University. His book, Abusing Science, thoroughly analyzes the books written by Henry M. Morris and Duane Gish, who could be called the founders of creationism, and concluded that creation science abuses not only evolutionary theory but also science in general, ${ }^{17}$ exposing creation science through emotionally detached analysis unlike Daniel Dennet and Richard Dawkins, who criticized creationism while touting their atheism. ${ }^{18}$

Stephen J. Gould argues that creationism is not science, and therefore its assertions are meaningless and self-contradictory. According to him, what is important is that evolutionism is a theory as well as a fact. Even if scholars challenge evolutionism with other competing theories, facts do not vanish. ${ }^{19}$ Early on, Darwin established the facts of evolution and temporarily proposed the theory of natural selection as its mechanism. After more than a hundred years of severe trials, evolutionary theory has now become an established theory in biology. This theory does have problems, and it is important to recognize that at worst there is a possibil-

17 Philip Kitcher, Abusing Science: The Case against Creationism (Cambridge: MIT Press, 1982), 124-64.

18 Daniel C. Dennet, Darwin's Dangerous Idea (New York: Simon \& Schuster, 1995), 17-23; Richard Dawkins, The God Delusion (London: Bantam Books, 2006), 15660.

19 Stephen J. Gould, “Evolution as Fact and Theory,” Discover 2 (May 1981). 
ity for it to be overturned. However, the fact is that evolution is supported by firm proof.

In the 1980 s, the creation science movement held up the banner of "intelligent design." Intelligent design asserts that a naturalistic explanation of biological reality is impossible, and biological reality can only be explained through intellectual causes. ${ }^{20}$ Proponents of intelligent design claim that their belief is scientific and provides an experiential proof of the existence of God. They also assert that intelligent design needs to be taught as an alternative to evolutionary theory in high school science classes. The term "intelligent design" came to be used after the United States Supreme Court's Edwards vs. Aguillard decision, which barred the teaching of creation science alongside evolutionary theory in public schools, as the Constitution bans the state from funding any religion. Intelligent design is seen in Europe and Turkey, an Islam country, but it is not different from creation science in that it is a pseudo-science and a reproduction of creation science. Interestingly, the Korean Association for Creation Research did not even change its name to include the term "intelligent design."

Six years after the enactment of the 1981 equal time law in Arkansas and Louisiana, which mandated public schools to provide equal time to creationism and evolutionism, the United States Supreme Court ruled the law unconstitutional. In 2005, a Pennsylvania court ruled that teaching intelligent design in public schools was unconstitutional. In 1999, the second edition of Science and Creationism: A View from the National Academy of Sciences was published, 15 years after the first edition. ${ }^{21}$ Scientists universally accepted the evolution of the universe, earth, and life, and the United States National Academy of Sciences confirmed that

20 William A. Dembski, ed., Mere Creation: Science, Faith \& Intelligent Design (Downers Grove: InterVarsity Press, 1998).

21 National Academy of Sciences, Science and Creationism: A View from the National Academy of Sciences, Second Edition (Washington, D.C.: National Academy Press, 1999). 
there was no place for creationism in the science curricula. In 1996, Pope John Paul II delivered a message to the Pontifical Academy of Sciences, stating that the Catholic Church supports scientists' evolutionary theory.

The first decade after the founding of the Korean Association for Creation Research was a decade of terror. The KACR was a group with great financial power, authority, and manpower. Initially, scientists were angry and ready to fight, but soon decided to take a step back and stay silent. When objections to my article against creationism published in the Hankyoreh poured in, I had no intention to respond but said that others should be given an opportunity to respond to all the criticism. However, the newspaper refused my request, saying that the pressure from the creationists was too strong. ${ }^{22}$ Elder biology education professors also lamented the situation, where they could not but stay silent.

It is quite amazing how the situation has changed after 30 years. In 2017, when the Moon Jae-in administration began, the fact that some of the candidates for high-ranking positions were creationists became a huge issue. In particular, Pak Sŏngjin, the Minister of SMEs and Startups designate, was found to have links with creation science during his confirmation hearing and ultimately withdrew himself from consideration. Prior to the Mun Chaein administration, there was a rumor that an important official of the KACR took a position on the Commission on Presidential Transition for the Park Geun-hye administration, and as a result the Ministry of Science and Technology was renamed the Ministry of Science, ICT, and Future Planning. ${ }^{23}$ The head of the commission repeating the

22 Song Sang-yong, "Pŏbjŏng-e Sŏn Ch'angjoron Sibi (Pros and Cons on Creationism in the Court)," Hankyoreh Shinmun, February 10, 1990; "Wŏnsungi Chaep'an Tasi Hal Kŏn'ga? (Monkey Trial Again?)” Hankyoreh 214 (April 1994).

23 Kim Woo Jae, "Kungnipdae-e Chinhwasaengmulhak-ŭl! (Evolutionary Biology Professors at National Universities!)” Hankyoreh Shinmun, July 17, 2017. The Korean name for the Ministry of Science, ICT and Future Planning is "Mirae Ch'angjo Kwahakbu." The second word, "ch'angjo" is the same word for "creation." In English, "ch'angjo (creation)," which was translated in conjunction with "mirae (future)" into Future Planning. 
expressions "creative economy" and "creation science" was caught on TV news as well. Some believed that the Pak administration's controversial "creative economy" was coined in conjunction with "creation science." Scientists, philosophers, and civic groups arose in objection. It has now become a thing of the past, but people also criticized the president of the KACR for becoming the head of a higher education institution and receiving an honorary doctorate from KAIST (Korea Advanced Institute of Science and Technology). Such criticisms against creation science were favorably received by the media, and the KACR is not in a position to lodge protests. However, when it comes to the public, creation science is a completely different matter. According to a survey conducted by EBS in 2009, 30 percent of the Korean people do not accept the theory of evolution, while 60 percent believe that creation science and evolutionary theory should both be taught in schools. It is time science educators reflect on their inactivity and start teaching evolutionary theory properly.

\section{Conclusion}

The clash between science and the Catholic Church over cosmology in the seventeenth century ended with the victory of science over religion. However, the conflict between evolutionary theory and creationism continues until today. As long as creationism stays confined to the church, there is no problem. At the Evolution versus Creation Symposium, one biology professor who served as a deacon at his church said, "I teach evolution in college, and I say that creationism is right when giving sermons at my church." If people believed that the two theories are not contradictory, there would not have been any issue. The problem occurred when the fundamentalists labeled creationism as a science. Science and religion each have its own territory. When one encroaches on the other, that is when problems arise. Mixing science and religion has created a monster, and creationism needs to separate itself from science and return to the purely religious domain. 
Darwin, an Anglican who was once absorbed in natural theology as a student, abandoned his faith when he became convinced of evolution at the Galapagos Islands. When he died in 1882, his family wanted to hold a private funeral and bury him in his hometown of Down, but Darwin was ultimately buried near Newton's grave at Westminster Abbey due to the strong public opinion that he should receive treatment suitable for a great scientist. The Darwin Memorial Fund was launched, and its sponsors included the Archbishops of Canterbury and York, and the Bishop of London. Famous physicist Stephen Hawking, who is a known atheist, was recently buried at Westminster Abbey as well, between Newton and Darwin. Unlike the United States, the United Kingdom sets a model example, demonstrating how religion and science can coexist in peace.

\section{References}

1 Alexander, Denis R. and Ronald L. Numbers, eds. Biology and Ideology from Descartes to Dawkins. Chicago: University of Chicago Press, 2010.

2. Barbour, Ian G. Religion and Science: Historical and Contemporary Issues. New York: Harper, 1997.

3. Bowler, Peter J. Darwin: Off the Record. London: Watkins Publishing, 2010.

4. Brockman, John. Intelligent Thought: Science versus the Intelligent Design Movement. New York: Vintage Books, 2006.

5. Brooke, John Hedley. Science and Religion: Some Historical Perspectives. Cambridge: Cambridge University Press, 1991.

6. Dawkins, Richard. The God Delusion. London: Bantam Books, 2006.

7. Davies, Merryl Wyn. Darwin and Fundamentalism. Cambridge: Icon Books, 2000.

8. Dembski, William A., ed. Mere Creation: Science, Faith \& Intelligent Design. Downers Grove: Inter Varsity Press, 1998.

9. Dennet, Daniel C. Darwin's Dangerous Idea. New York: Simon \& 
Schuster, 1995.

10. Dewey, John. The Influence of Darwin on Philosophy and Other Essays in Contemporary Thought. Bloomington: Indiana University Press, 1965.

11. Draper, John William. History of the Conflict between Religion and Science. New York: D. Appleton, 1874.

12. Gould, Stephen Jay. "Evolution as Fact and Theory." Discover 2 (May 1981): 34-7.

13. Greene, John C. Darwin and the Modern World View. Baton Rouge: Louisiana State University Press, 1961.

14. Greene, John C. The Death of Adam: Evolution of Its Impact on Western Thought. Ames: Iowa State University Press, 1996.

15. Gish, Duane T. Evolution: The Fossils Say No. San Diego: CreationLife Publishers, 1979.

16. Jang, Dayk. 'Ch'angjogwahak-ŭn Kacha Kwahak-in'ga? (Is Creation Science a Pseudoscience?)” Epi 1 (September 2017): 170-80.

17. Kim, Young-Gil (Kim, Yŏnggil). "Ch'angjo Kwahak Sayŏk 20 nyŏnŭl Torabomyŏ" (Looking back to twenty years of the creation science mission)." In Han'gukch'angjogwahakhoe Isimnyŏnsa: 19812001 (Twenty-Year History of the Korean Association for Creation Research, 1981-2001). Seoul: Han'guk ch'angjogwahakhoe, 2001.

18. Kim, Hie-Joon. "Kwahak-gwa Chonggyo-ŭi Kaltŭng (Conflicts between Science and Religion)." Chisik-ŭi Chip'yŏng 4 (June 2008: 108-23.

19. Kim, Woo Jae. "Kungnipdae-e Chinhwasaengmulhak-ŭl! (Evolutionary Biology Professors at National Universities!)" Hankyoreh Shinmun, July 17, 2017.

20. Kitcher, Philip. Abusing Science: The Case against Creationism. Cambridge: MIT Press, 1982.

21. Kitcher, Philip. Living with Darwin: Evolution, Design, and the Future of Faith. Oxford: Oxford University Press, 2007.

22. Lecky, William Edward Hartpole. A History of the Rise and Influence of Rationalism in Europe, 2 vols. New York: D. Appleton, 1865. 
23. Lee, Byung-Hoon. 'Kwahakjŏk Kun'gŏ ŏmnŭn 'Ch'angjogwahak' Creation Science without Scientific Ground)." Sisa Journal, Decembr 12, 1991.

24. Lee, Byung-Hoon. "Chinhwa-nŭn Kasŏl Anin Sasil (Evolution is Fact, Not Hypothesis).” Hankyoreh Shinmun, July 19, 2012.

25. Lindberg, David C. and Ronald L. Numbers, eds. God and Nature. Historical Essays on the Encounter between Christianity and Science. Berkeley: University of California Press, 1986.

26. Morris, Henry M. Scientific Creationism. San Diego: Creation-Life Publishers, 1972.

27. Morris, Henry M. Introducing Creationism in the Public Schools. San Diego: Creation-Life Publishers, 1974.

28. National Academy of Sciences. Science and Creationism: A View from the National Academy of Sciences. Second Edition. Washington, D.C.: National Academy Press, 1999.

29. Nelkin, Dorothy. The Creation Controversy: Science or Scripture in the Schools. New York: Norton, 1982.

30. Niebuhr, Reinhold. "Christianity and Darwin's Revolution." In $A$ Book That Shook the World, edited by Julian Huxley et al. Pittsburgh: University of Pittsburgh Press, 1958.

31. Numbers, Ronald. Ch'angjoronjadŭl (The Creationists: From Scientific Creationism to Intelligent Design), translated by Shin Chunho. Seoul: Holy Wave Plus, 2016.

32. Numbers, Ronald. "Creationism, Intelligent Design, and Modern Biology." In Biology and Ideology from Descartes to Dawkins, edited by Denis R. Alexander and Ronald L. Numbers. Chicago: University of Chicago Press, 2010.

33. Park, Hee-Joo. Anti-Creationism in America. PhD diss., University of Melbourne, 1997.

34. Park, Hee-Joo. “Ch'angjo-chinhwa Nonjaeng Ŏtŏke Haesŏk-hal Kŏt In'ga (How to Interpret Creation-Evolution Controversy)." Han'guk Kwahaksa Hakhoeji (Journal of the Korean History of Science Society) 21, no. 1 (June 1999): 112-20. 
35. Park, Hee-Joo. "Tawŏnjuŭi Sidae-ŭi Kwahak-gwa Chonggyo (Science and Religion in the Pluralist Age)." Sinanggwa Hangmun (Faith and Scholarship) 4, no. 1 (March 1999): 21-35.

36. Park, Hee-Joo. "Sangdaejuŭi-wa Kwahak-Pigwahak Kubunmunje: Ch'angjo-Chinhwa Nonjaeng-ǔi Kyong'u (Relativism and the Demarcation Problem in the Creation-Evolution Controversy)." Kwahakch'órhak (Korean Journal for the Philosophy of Science) 3, no. 2 (September 2000): 49-65.

37. Park, Hee-Joo. "The Politics of Anti-Creationism: The Committees of Correspondence." Journal of the History of Biology 33, Issue 2 (2000): 349-70. https://doi.org/10.1023/A:1004821731846.

38. Park, Hee-Joo. "The Creation-evolution Debate: Carving Creationism in the Public Mind." Public Understanding of Science 10, no. 2 (2001): 173-86.

39. Park, Hee-Joo. "Tawin-ŭi Chinhwaron-gwa Chonggyo (Darwin's Evolutionary Theory and His Religion)." Han'guk Kwahaksa Hakhoeji (Journal of the Korean History of Science Society) 31, no. 2 (December 2009): 359-75.

40. Ruse, Michael. But Is It Science?: The Philosophical Questions in the Creation - Evolution Controversy. Buffalo: Prometheus Books, 1988.

41. Ruse, Michael. The Evolution - Creation Struggle. Cambridge: Harvard University Press, 2000.

42. Russell, Bertrand. Religion and Science. London: Thornton Butterworth, 1935.

43. Song, Sang-yong. "Tawinijŭm-gwa Mokjŏngnon (Darwinism and Teleology).” MA diss., Seoul National University, 1967.

44. Song, Sang-yong. "Adam-ŭi Chugŭm-gwa Puhwal (The Death and Rebirth of Adam)." Kyobomun'go 1-2 (1982): 24-26.

45. Song, Sang-yong. “Ch’ŏndongsŏl-gwa Chidongsŏl, Ch'angjorongwa Chinhwaron (Heliocentric Theory vs. Geocentric Theory, Creation vs. Evolution)." Samok 80 (March 1982): 22-30.

46. Song, Sang-yong. "Saeroun Tojŏn Pannŭn Chinhwaron (The New 
Challenge to Evolutionary Theory)." Chŏnggyŏngmunhwa 207 (1982): 295-300.

47. Song, Sang-yong. “Ch'angjokwahak-ŭn Kwahagin'ga? (Is Creation Science a Science?)." Kwahak-gwa Kisul (Science and Technology) 16, no. 9 (1983): 59-63.

48. Song, Sang-yong. "Ch'angjokwahak Undong (Creation Science Movement)." Hallym Hakpo 19 (1986).

49. Song, Sang-yong. "Ch'angjokwahak-gwa Minjoksagwan (Creation Science and Nationalist View of History)." Saehan Shinmun, June 23, 1986.

50. Song, Sang-yong. “Chinhwaron, Ch'angjosŏl and Ch'angjokwahak (Evolutionary Theory, Creationism and Creation Science)." Ŏlongwa Pip'yŏng 7 (1989): 156-60.

51. Song, Sang-yong. "Pŏbjŏng-e Sŏn Ch'angjoron Sibi (Pros and Cons on Creationism in the Court)." Hankyoreh Shinmun, February 10, 1990.

52. Song, Sang-yong. "Wŏnsungi chaep'an (Monkey Trial)." Mal 5 (1992).

53. Song, Sang-yong. "Ch'angjogwahak-gwa Reagan (Creation Science and Reagan)." Mal 6 (1992).

54. Song, Sang-yong. "Kwahak-iran irŭm-ŭi kwangshin (The Fanaticism Called Science)." Kangwon Ilbo, June 3, 1992.

55. Song, Sang-yong. “Wŏnsungi Chaep’an Tasi Hal Kŏn'ga? (Monkey Trial Again?)" Hankyoreh 214 (April 1994).

56. Song, Sang-yong. "Ch'ŏrakjadŭl-i Pon Tawin (Darwin Viewed by Philosophers)." Tawin T'ansaeng 200 Chu-nyŏn Kinyŏm Yŏnhaphaksuldaehoe Charyojip (Proceedings of the United Conference in Commemoration of the Bicentennial of Darwin's Birth), 2009, 3-7.

57. Song, Sang-yong. "Inmunhakja Tawin (Darwin as a Humanist)." Special Lecture, Korea Research Foundation, November 7, 2009.

58. Song, Sang-yong. "Chonggyo-wa Kwahak (Religion and Science)." Chonggyomunhwahakbo (Journal of Religious Science \& Culture) 9 
(May 2012): 5-21.

59. Sung, Young-gon. "Kwahak-gwa Chonggyo (Science and Religion)." Han'guk Kwahaksa Hakhoeji (Journal of the Korean History of Science Society) 20, no. 2 (December 1998): 239-64.

60. Sung, Young-gon. "Yŏksa Sok-ŭi Chinhwaron: Tawin, Tawinjuŭi, Kŭrigo Chonggyo (Darwin, Darwinism, and Religion)." Han'guk Kwahaksa Hakhoeji (Journal of the Korean History of Science Society) 31, no. 2 (December 2009): 325-57.

61. White, Andrew Dickson. History of the Warfare of Science with Theology in Christendom. 2 vols. New York: D. Appleton, 1896.

62. Zhang, Hwe Ik (Chang Hoeik). Kwahak-gwa Metakwahak (Science and Metascience). Seoul: Hyŏnamsa, 2012. 


\section{$\langle$ Abstract $\rangle$}

\section{The Creation Science Movement in Korea: A Perspective from the History and Philosophy of Science}

In the seventeenth century, science and religion clashed over cosmology. The relationship between science and religion was at extreme odds at the Galileo trials but softened in the twentieth century when the Catholic Church accepted the new science. Meanwhile, the evolutionary theory proposed in the nineteenth century lowered the status of humans to animals and damaged faith in biblical inspiration. The Scopes Trial in the southern United States in the 1920s was the result of the defiance of the Protestants, who insisted on a literal interpretation of the Bible. "Creation science," which began to thrive in the western United States in the 1960s, insisted on equal time in schools alongside evolutionary theory. After repeated defeat in court, creation science is desperately trying to get its footing in science with a new name: intelligent design. The creation science movement that came Korea in the 1980s joined hands with Christian obscurantism and is running amok. When creationism pretends to be science, it is an unfair interference of religion in science. Creation science is a pseudoscience that cannot be accepted as science.

Keywords: religion, science, Christianity, geocentric theory, heliocentric theory, Galileo Affair, Darwin, evolutionary theory, fundamentalism, Monkey Trial, creation science, Intelligent Design. 


\section{〈국문초록〉}

\section{과학사 - 과학철학의 관점에서 본 한국의 창조과학운동}

송상용 (한림대 명예교수 / 한국과학기술한림원 종신회원)

과학과 종교는 17 세기에 우주론을 둘러싸고 충돌했다. 갈릴레오 재판에서 최악 이었던 과학과 종교의 관계는 가톨릭 교회가 20세기에 들어와 새 과학을 수용함 에 따라 원만히 해결되었다. 그러나 19세기에 나온 진화론은 인간을 동물로 떨어 뜨리고 성서에 나오는 영감의 믿음을 손상하는 결과를 가져왔다. 1920년대 미국 남부에서 있었던 원숭이재판은 성서 축자해석을 고집한 개신교의 반항이었다. 1960 년대 미국 서부에서 나온 '창조과학'은 창조론을 진화론과 같은 시간 가르치 라는 무리수를 두었고 법정에서 연패를 겪으면서 '지적 설계'라는 새 이름으로 발 악을 하고 있다. 1980년대에 한국에 들어온 창조과학운동은 보수적인 그리스도교 의 몽매주의와 손잡고 갖은 횡포를 다하고 있다. 창조론이 교회 밖으로 나와 과학 을 사칭하는 것은 과학에 대한 부당한 간섭이다. 창조과학은 용납할 수 없는 사이 비과학이다.

주제어: 종교, 과학, 기독교, 지구중심설, 태양중심설, 갈릴레오 재판, 다윈, 진 화론, 근본주의, 원숭이재판, 창조과학, 지적 설계 
